\title{
Immunostimulatory properties of a novel adjuvant administered with inactivated influenza virus vaccine
}

\author{
Vincent Wellemans, Sylvette LAURENT*, Pierre HÉLIE, \\ Youssef ELAzHARY
}

\begin{abstract}
Faculté de médecine vétérinaire, Université de Montréal, PO Box 5000, Saint-Hyacinthe, Qc, J2S 7C6, Canada
\end{abstract}

(Received 27 November 2005; accepted 12 June 2006)

\begin{abstract}
The immunopotentiating activity of a new delivery system was investigated comparatively to Alhydrogel ${ }^{\circledR}$ adjuvant, as an antiviral inactivated vaccine after one injection. The efficiency of the new formulation (BioMed) was evaluated with an inactivated porcine strain of influenza (A/Sw/IN/1726/88 H1N1) in the pig model. The first assessment criteria was the follow-up of selected immunological parameters such as, antibody levels, lymphoproliferation, double positive $\mathrm{CD} 4^{+} \mathrm{CD}^{+} \mathrm{T}$ lymphocytes and cytokine production (IL-2, IL-4, IFN- $\gamma$ ). The second criteria was the estimate of the protection level of animals exposed to a homologous challenge of $50 \mathrm{PID}_{50}$ one month after a single immunizing or control injection. In the BioMed group of animals, 4 pigs (out of 6) were free of macroscopic lesion, while lesions could be seen in all individuals of other groups and virus was isolated in only one animal, whereas all other animals of other groups had virus in their lungs. This better protection of BioMed animals seems to be correlated mainly with higher levels of antibodies and to a lesser extent with a slightly better CMI response and probably with the production of memory $\mathrm{CD} 4^{+} \mathrm{CD} 8^{+} \mathrm{T}$ cells.
\end{abstract}

H1N1 swine influenza virus / immunopotentiating adjuvant / inactivated vaccines

\section{INTRODUCTION}

There is a continuous focus to find new immunopotentiating adjuvants for vaccines and to improve their efficiency by optimizing the level and duration of the immune response. New compounds should present the desired combination of optimal immune stimulating properties with minimal-to-no tissue irritation. Moreover, for vaccines such as inactivated vaccines or subunit vaccines, a more efficient delivery

* Corresponding author:

sylvette.laurent-lewandowski@umontreal.ca is desirable since they usually need more than one dose [26].

The objective of this study was to evaluate the efficacy of a new delivery system (BioMed) as a single-dose adjuvant for inactivated vaccine. The formulation of this carrier, including immuno-stimulatory ingredients of pharmaceutical quality, was designed for a high entrapment capacity of proteins. It is a biphasic system, which combines a colloidal phase, formulated from a negatively charged oil-inwater emulsion, and an Alhydrogel ${ }^{\circledR}$ phase positively charged at physiological $\mathrm{pH}$. It offers the opportunity to modulate antigen release as well as to direct targeting 
to antigen-presenting-cells by controlling emulsion droplet size and total charge [11].

In order to evaluate this formulation as an adjuvant, the swine influenza model has been used considering its world wide concern. Swine influenza is a highly contagious acute viral disease of the respiratory tract in pigs, which causes considerable economic damage primarily due to reduced weight gain in finishing pigs and reduced reproductive performance of sows $[6,10]$. Influenza is also a potential zoonotic disease because pigs possess sialic receptors for both mammalian and avian strains; they can serve as mixing vessel hosts and be a source of new influenza strains that can be a threat for humans $[23,32,37]$. Moreover, only a few vaccination studies have been performed in pigs, and little is known about the correlation between the different effectors of the immune system (especially the cell mediated immunity) and protection against influenza. Furthermore, the swine immune system is unique in that there is a large percentage of double positive $\mathrm{CD} 4^{+} \mathrm{CD} 8^{+} \mathrm{T}$-cells (DP) in the peripheral blood of mature animals [27, 29, 31, 39]. This sub-population, which increases with the age of the pig, contains memory cells $[27,38]$. In this study, one purpose was to appreciate the level of stimulation of these DP with recall antigen in vitro.

In a preliminary attempt to appraise the BioMed adjuvant formulation, mice studies were conducted using an (A: H1N1) swine influenza strain. These studies showed that the administration of one dose of inactivated whole-virus antigen in combination with BioMed formulation is able to completely protect inbred mice against a homologous challenge of $100 \mathrm{MID}_{50}{ }^{1}$. A second step, and the purpose of this study, was to test the immunopotentiating effect of this formulation comparatively to aluminium hydrox-

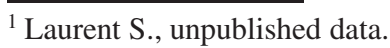

ide (Alhydrogel ${ }^{\circledR}$ ), in the swine model, which is a natural influenza host.

\section{MATERIALS AND METHODS}

\subsection{Virus production and purification}

The Influenza virus (A/Swine/Indiana/ 1726/88 H1N1) received from Dr Christopher W. Olsen (University of WisconsinMadison, USA) was propagated in 9-dayold embryonated chicken eggs. Infected allantoic fluid was harvested $72 \mathrm{~h}$ later, and the virus was concentrated by precipitation with $8 \%$ polyethylene glycol (mol wt $8000)$. Concentrated virus was purified by centrifugation onto a $15-60 \%(\mathrm{~W} / \mathrm{V})$ sucrose gradient followed by centrifugation through a $30 \%$ sucrose cushion. The pellet was resuspended (overnight at $4{ }^{\circ} \mathrm{C}$ ) in Hepes $100 \mathrm{mM}$. The purified preparation was stored at $-80{ }^{\circ} \mathrm{C}$ and was evaluated as described by Barett and Inglis [1] for its content in haemagglutinin and protein (BCA Kit, Pierce); its tissue culture infectious dose $\left(\mathrm{TCID}_{50}\right)$; and its egg infectious dose $\left(\mathrm{EID}_{50}\right)$ by the method of Thompson [33].

\subsection{Vaccines and vaccination protocol}

- Inactivated virus: The purified virus was inactivated with $0.025 \%(\mathrm{~V} / \mathrm{V})(37 \%$ formaldehyde (Fisher)) at $4{ }^{\circ} \mathrm{C}$ overnight. The inactivation was confirmed by inoculation in embryonated eggs. The sterility of the preparation was verified by streaking Bacto Columbia Agar and modified Bacto Sabouraud Agar (Difco, Detroit, Michigan, USA).

- The "BioMed" delivery system/adjuvant has been prepared by microfluidizing in a volume of $100 \mathrm{~mL}$ at $12000 \mathrm{psi}$ (High pressure homogenizer Emulsiflex ${ }^{\circledR}$ C5, Avestin, Inc., Ottawa, ON, Canada) $4 \mathrm{~mL}$ of 2, 6, 10, 15, 19, 23-hexamethyltetracosane (Squalane, Sigma \# S-4510), 
$1 \mathrm{~mL}$ of sorbitan trioleate (Span 85, Sigma \# S-7135), $1 \mathrm{~mL}$ of polyoxyethylenesorbitan monooleate (Tween 80, Sigma \# P-8074), $100 \mathrm{mg}$ of coenzyme Q10 (Ubiquinone 50, Sigma \# C-9538), $100 \mathrm{mg}$ of dihexadecyl phosphate (Dicetylphosphate, Sigma \# D-2631), $20 \mathrm{mg}$ of vitamin A (retinol synthetic, Sigma R7632), $100 \mathrm{mg}$ of vitamin $\mathrm{E}$ ( $\alpha$-tocopherol, Sigma \# T-3251) as follows: briefly, appropriate volumes of ubiquinone 50 , dicetylphosphate, vitamins $\mathrm{A}$ and $\mathrm{E}$ dissolved in methanol:chloroform $(2: 1)$ were added in a $100 \mathrm{~mL}$ bottle, and the organic solvent was evaporated using a nitrogen gas stream before adding appropriate amounts of Squalane, Span 85 and Tween 80. The mixture was then microfluidized three times in $100 \mathrm{~mL}$ of phosphate buffered saline (PBS: 8 g/L sodium chloride, Sigma \# S7653, $0.2 \mathrm{~g} / \mathrm{L}$ potassium chloride, Omega \# PK-111, 0.2 g/L potassium phosphate monobasique, Fisher Scientific \# P285 B and $1.15 \mathrm{~g} / \mathrm{L}$ of dibasic sodium phosphate, Sigma S-9763). The obtained emulsion was finally sterilized by autoclaving at $120{ }^{\circ} \mathrm{C}$ for $15 \mathrm{~min}$. Finally, the emulsion phase $(14 \mathrm{~mL})$ was mixed with $980 \mathrm{mg}$ of aluminium hydroxide (Alhydrogel ${ }^{\circledR} 1.3 \%$, Brenntag Biosector, \# A-1090 S).

- Vaccination protocol: Twenty-four, 5-week old, specific pathogen free, Yorkshire-Landrace pigs were randomized, divided into four groups of six pigs, and housed in isolation units. Each piglet, depending on its group, received the following injection:

(1) negative control (Ctl-): $1 \mathrm{~mL}$ PBS;

(2) antigen alone (Ag): $500 \mu \mathrm{L}$ inactivated virus $+500 \mu \mathrm{L}$ PBS;

(3) antigen + Alhydrogel $^{\circledR}$ (Ag+Alhydrogel): $(500 \mu \mathrm{L}$ inactivated virus + $300 \mu \mathrm{L}$ PBS $+200 \mu \mathrm{L}$ of aluminium hydroxide (Alhydrogel ${ }^{\circledR} 1.3 \%$ ), mixed by vortexing for $15 \mathrm{~min}$;

(4) antigen + BioMed adjuvant (Ag+ BioMed): $500 \mu \mathrm{L}$ inactivated virus +
$500 \mu \mathrm{L}$ BioMed adjuvant mixed by vortexing for $15 \mathrm{~min}$.

Each vaccine preparation contained the same amount (1024 HAU) of inactivated antigen. These different preparations $(1 \mathrm{~mL})$ were slowly administered as two (500 $\mu \mathrm{L}$ each) deep intramuscular injections into the neck.

\subsection{Challenge protocol}

On day 31 post-immunization, all pigs were challenged, after tranquillisation (intramuscular injection of Ketamine (Rogar/STB) at $20 \mathrm{mg} / \mathrm{kg}$ of body weight and Stresnil (Janssen Phamaceutica) at $2.2 \mathrm{mg} / \mathrm{kg}$ ), with the Indiana/1726/88 strain by intranasal nebulisation of infected allantoïc fluid (1.6 HAU/animal, corresponding to 50 pig infectious dose $\left.\left(\mathrm{PID}_{50}\right)\right)$. Four days after challenge, piglets were euthanized.

\subsection{Serology}

Blood samples of all pigs were collected from the anterior vena cava on day 0 (pre-immunization), on days $3,10,17$, 24, 31, 33, and 35 (post-immunization). Days 33 and 35 correspond to days 2 and 4 post-challenge, respectively. The sera were adsorbed onto chicken erythrocytes to remove non-specific inhibitors of haemagglutination. Sera were examined by the haemagglutination inhibition test (HI) and by seroneutralisation (SN) test on Madin Darby canine kidney cells (MDCK) against the SW/IN/1726/88 virus. HI and SN tests were performed according to standard procedures.

\subsection{Harvesting of peripheral blood mononuclear cells (PBMC)}

PBMC were isolated from heparinised blood samples by gradient centrifugation as follows: peripheral blood was 
diluted 1:2 (V/V) in PBS-gentamycine, (50 $\mu \mathrm{g} / \mathrm{mL})$, overlayed onto ficollhypaque, (Histopaque 1077; Sigma), and centrifugated at $400 \times g$ for $30 \mathrm{~min}$ at $11{ }^{\circ} \mathrm{C}$. PBMC were obtained from the ficoll/plasma interface and washed two times with PBS-gentamycine. The cells were resuspended $\left(5 \times 10^{6}\right.$ cells $\left./ \mathrm{mL}\right)$ in RPMI supplemented with $10 \%$ FCS, $2 \mathrm{mM}$ L-glutamine, $2 \mathrm{mM}$ sodium pyruvate, $5 \times 10^{-5} \mathrm{M}$ 2-mercaptoethanol, $50 \mu \mathrm{g} / \mathrm{mL}$ gentamycine and buffered with $1 \mathrm{M}$ Hepes (pH 7.2-7.4).

\subsection{In vitro lymphoproliferation}

Ninety-well round-bottomed microtiter plates (Costar, Cambridge, MA, USA) were seeded with $100 \mu \mathrm{L}$ of $5 \times 10^{6} / \mathrm{mL}$ PBMC. Test wells were prepared by adding $100 \mu \mathrm{L}$ medium containing purified virus (final concentration: $10 \mathrm{HAU} / \mathrm{mL}$ ). Control wells were prepared by adding either $100 \mu \mathrm{L}$ of pokeweed $(5 \mu \mathrm{g} / \mathrm{mL})$ (Sigma L8777), $100 \mu \mathrm{L}$ of Concanavalin A $(2 \mu \mathrm{g} / \mathrm{mL})($ Sigma C5275), or $100 \mu \mathrm{L}$ of medium alone (no stimulation). The plates were incubated for 3 days at $37{ }^{\circ} \mathrm{C}$ in $5 \% \mathrm{CO}_{2}$ humidified atmosphere. Six hours prior to harvesting, $0.2 \mu \mathrm{Ci}$ of methyl$\left[{ }^{3} \mathrm{H}\right]$ thymidine (ICN, 24059) in $10 \mu \mathrm{L}$ of medium was added to each well. The cells were harvested onto a glass-fiber filter (Filter Mat 11731 - Skatron Instruments), using a Skatron Instrument cell harvester (Cell Harvester 11019). Incorporated radioactivity was measured by liquid scintillation counting (Beckman LS6500, Multi Purpose Scintillation). Treatments were run in triplicate and proliferation was evaluated as (cpm with virus - cpm without virus).

\subsection{Preparation and analysis of cells by flow cytometry}

PBMC were analyzed for expression of cell surface antigens by flow cy- tometry. Twenty-four-well, flat-bottomed plates were seeded with $500 \mu \mathrm{L}$ of $5 \times$ $10^{6} \mathrm{PBMC} / \mathrm{mL}$. Test wells were prepared by the addition of $500 \mu \mathrm{L}$ of purified virus (10 HAU/mL as final concentration). Control wells were prepared by the addition of $500 \mu \mathrm{L}$ of complete RPMI medium alone (negative control). The plates were incubated for $72 \mathrm{~h}$ at $37{ }^{\circ} \mathrm{C}$ in $5 \% \quad \mathrm{CO}_{2}$ humidified atmosphere. Following incubation, the cells were recovered by centrifugation, washed and distributed in 96well V-bottomed microtiter plates. The cells were stained with primary antibodies to swine leukocyte surface antigens, $\left(\mathrm{IgG}_{2 \mathrm{~b}}\right.$-mouse anti-swine $\mathrm{CD} 4$ (Serotec MCA 1749) and $\mathrm{IgG}_{2 \mathrm{a}}$-mouse anti-swine CD8 (Serotec MCA 1223), diluted 1:50 in FACS-buffer) for $30 \mathrm{~min}$ on ice. The cells were then washed and incubated a second time for $30 \mathrm{~min}$ on ice with goat antimouse $\mathrm{IgG}_{2 \mathrm{~b}}$ fluorescein isothiocyanate (FITC)-conjugated and anti-mouse $\mathrm{IgG}_{2 \mathrm{a}}$ phycoerythrin (PE)-conjugated. Then, the cells were washed and their fluorescence was measured using a FACScan flow cytometer (Becton Dickinson, FACScan). The results were analyzed by the Cell Quest program (Becton Dickinson application).

\subsection{Cytokine production assays}

Cytokine production by PBMC was assayed in 24-well, flat-bottomed plates. The wells were seeded with $500 \mu \mathrm{L}$ of $5 \times$ $10^{6} \mathrm{PBMC} / \mathrm{mL}$. The test wells were prepared by the addition of $500 \mu \mathrm{L}$ of purified virus (10 HAU/mL as final concentration). Control wells were prepared by the addition of $500 \mu \mathrm{L}$ of complete RPMI medium alone (negative control). Plates were incubated for $72 \mathrm{~h}$ at $37{ }^{\circ} \mathrm{C}$ in $5 \% \mathrm{CO}_{2}$ humidified atmosphere. Culture supernatants were assayed by ELISA to determine levels of IL-2 (Biosource KSC0022), IL-4 (Biosource KSC0042), IFN- $\gamma$ (Biosource KSC4022). 


\subsection{Macroscopic and histopathological lung examinations after homologous challenge}

The pigs were killed on day 4 after challenge inoculation. The total number of macroscopic lesions was determined. These lesions examined by standard histopathological techniques were classified in four categories depending on their intensity: absence of pathological modification (-); focal lesions limited to rare bronchioles $(+)$; a few bronchiole/bronchus $(++)$; many bronchiole/bronchus $(3+)$ and major bronchiole/bronchus alterations (4+). Viral isolation was performed from the same weight of randomly sampled lung tissues. The samples were homogenised in a mortar in cold PBS containing antibiotic (gentamycine $50 \mu \mathrm{g} / \mathrm{mL}$ ) and $10 \%$ FCS. Suspensions $10 \%(\mathrm{~W} / \mathrm{V})$ were centrifuged at $1000 \times g$ for $15 \mathrm{~min}$. The supernatant was collected, diluted 1:10 with PBS and subjected to viral titration. Dilutions $(0.1 \mathrm{~mL})$ were inoculated in embryonated eggs (6 eggs/dilution). After $72 \mathrm{~h}$ incubation at $37^{\circ} \mathrm{C}$, the allantoïc fluid was tested for haemagglutinating activity. Only one passage was made.

\subsection{Statistical analysis}

All data are presented as mean \pm standard error mean (SEM). Data presented in Figures 1 to 6 were analyzed by two-way repeated measures ANOVA with group as the between-subject factor and time as the within-subject factor. Tukey-Kramer posthoc tests were used to determine differences between pairs of groups at different time periods. Data presented in Figures 6 and 8 were analyzed by one-way ANOVA with group as the between-subject factor. Tukey-Kramer post-hoc tests were used to examine differences between pairs of groups. Differences between groups were

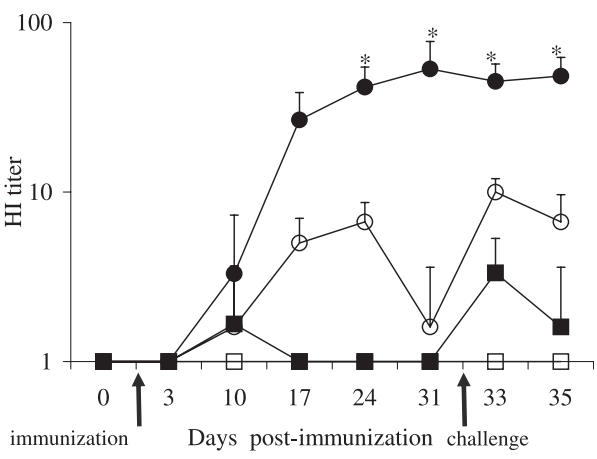

Figure 1. Mean HI titers against homologous strain in serum of pigs. The HI titer of each animal was determined by the hemagglutination inhibition test. Serum HI antibody responses of pigs following injection of PBS (Ctl- $\square)$ or inactivated $\mathrm{H} 1 \mathrm{~N} 1$ alone ( $\mathrm{Ag} \mathbf{\square})$ or with Alhydrogel ${ }^{\circledR}$ adjuvant (Ag+Alhydrogel $O$ ), or with BioMed adjuvant (Ag+BioMed $\bullet$ ), and challenged with homologous strain. The results represent the mean \pm SEM of six experimental pigs. Data points sharing the symbol $(*)$ are significantly different $(p<0.05)$.

considered significant if probability values of $p<0.05$ were obtained.

\section{RESULTS}

\subsection{The immunological response to vaccination}

\subsubsection{Serological response}

The level of protection given by an H1N1 influenza strain based vaccine in pigs is correlated with the serum antihemagglutinin (HI) level. Serum antibodies begin to be produced on day 10 after immunization (Fig. 1). At day 17 post-immunization, $\mathrm{HI}$ concentrations of the animals of group (Ag+BioMed) were significantly higher than those of group $(\mathrm{Ag}+$ Alhydrogel $)(p<0.05)$; they reached a maximum on day 31 (average of the group 1/50) and remained at this level during the post-challenge period. The significant difference of $\mathrm{HI}$ antibody production of the group (Ag+BioMed) compared 


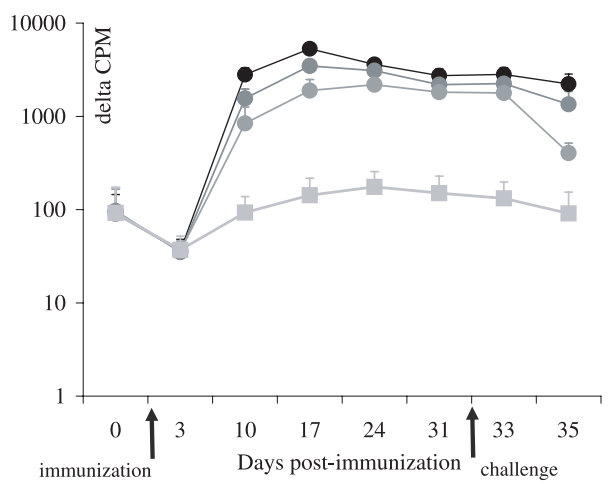

Figure 2. Mean influenza specific lymphocyte proliferation responses of PBMC of pigs after immunization with $(\mathrm{Ag}+\mathrm{BioMed})$ and challenge. Proliferation was expressed as the number of counts (mean of triplicate) of $\mathrm{H} 1 \mathrm{~N} 1$ influenza stimulated PBMC at a final concentration of $10 \mathrm{HAU} / \mathrm{mL}(1 / 10)(\bullet), 1 \mathrm{HAU} / \mathrm{mL}$ $(1 / 100)(\bullet)$ and 0.1 HAU (1/1000) (๑), minus the number of counts of non-stimulated PBMC (delta CPM). MOCK control was diluted in $1 / 10(\square)$. The results are presented as the mean $\pm \operatorname{SEM}(n=6)$.

to other groups was corroborated by the fact that only pigs of this group produced serum neutralizing antibodies (1/10-1/20) that were detectable from day 24 postimmunization (data not shown).

\subsubsection{Evaluation of the cell mediated immunity}

\subsubsection{Specific lymphoproliferation}

The cell-mediated immunity (CMI) acts as a direct regulator on the immune response and is essential for immunity against intra-cellular pathogens including viruses. Proliferation has been assessed with infectious virus (only a weak proliferation could be detected in the presence of inactivated virus). Firstly, as a control of specificity and sensibility, lymphoproliferation was evaluated after stimulation with a dilution of purified virus in

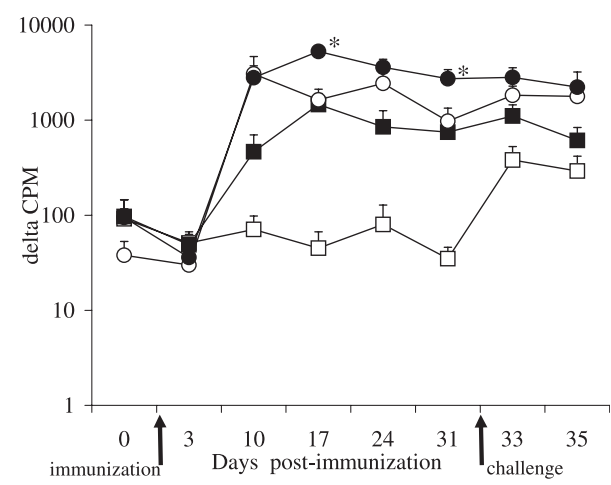

Figure 3. Mean influenza specific lymphocyte proliferation responses of PBMC of pigs after immunization and challenge. Pigs were inoculated intramusculary with PBS (Ctl- $\square)$ or with inactivated virus alone $(\mathrm{Ag} \mathbf{\square})$, or combined with Alhydrogel ${ }^{\circledR}(\mathrm{Ag}+$ Alhydrogel $O)$, or with BioMed adjuvant $(\mathrm{Ag}+\mathrm{BioMed} \bullet)$. Proliferation was expressed as the number of counts (mean of triplicate) of H1N1 influenza stimulated PBMC minus the number of counts of non-stimulated PBMC (delta CPM). The results are presented as the mean $\pm \operatorname{SEM}(n=6)$. Data points sharing the symbol $(*)$ are significantly different $(p<0.05)$.

the $(\mathrm{Ag}+\mathrm{BioMed})$ group or MOCK control (Fig. 2). The figure shows that, the lymphoproliferation is dose dependant and that the MOCK stimulation induces no (or weak) proliferation. Secondly (Fig. 3), for the three groups for which the vaccinal preparation contains antigen, PMBC proliferation was detectable at day 10 postimmunization, reached a maximum before day 24 and remained at this level. The lymphoproliferation was marginally higher $(p=0.03)$ at days $17(p=0.0003)$ and 31 $(p=0.0406)$ after immunization with the BioMed treatment.

\subsubsection{Evaluation of the relative percentage of $T$ lymphocytes $\mathrm{CD4}^{+} \mathrm{CD}^{+}$by flow cytometry}

We analyzed the role of the antigenic stimulation on the generation of 


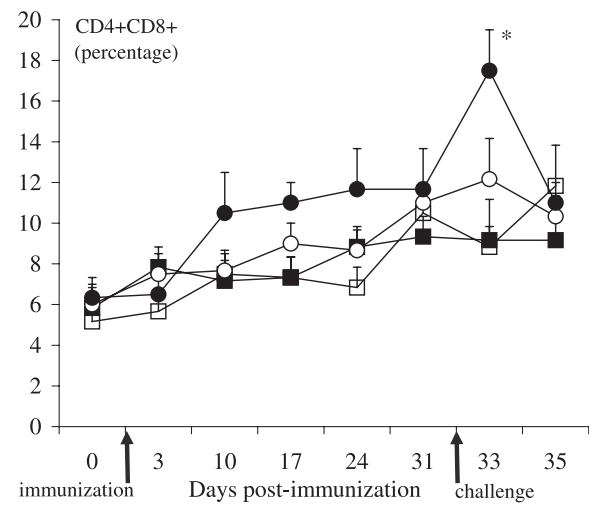

Figure 4. Flow cytometric analyses of $\mathrm{CD} 4^{+} \mathrm{CD}^{+}$lymphocytes recovered from pigs. A two-color flow cytometry analysis was used to evaluate lymphocytes collected from PBMC of pigs after immunization. For each group (Ctl- $\square ; \mathrm{Ag} \mathbf{\square}$; Ag+Alhydrogel $\bigcirc ; \mathrm{Ag}+\mathrm{BioMed}$ -), the cells were double stained with monoclonal antibodies directed against CD4 and CD8 (Materials and methods). The percentage represents the number of $\mathrm{CD} 4^{+} \mathrm{CD} 8^{+}$lymphocytes in the PBMC. The plotted results are the mean $(n=6) \pm$ SEM. Data point with the symbol $(*)$ is significantly different $(p=0.05)$.

$\mathrm{CD} 4^{+} \mathrm{CD} 8^{+}$because they could be involved in immunological memory. The relative percentage of the $\mathrm{CD} 4^{+} \mathrm{CD} 8^{+} \mathrm{T}$ cells was evaluated by cytometry (Fig. 4). During the pre-challenge period, there was no difference between the three groups of animals immunized with antigen, but after the challenge the $\mathrm{CD}^{+} \mathrm{CD}^{+}$population of the pigs of the (Ag+BioMed) group became marginally higher $(p=0.05)$ than that of (Ag+Alhydrogel) group and significant on day $33(p=0.0007)$. An evaluation of the other populations of lymphocytes $\left(\mathrm{CD} 4^{+} \mathrm{CD}^{-}\right.$and $\left.\mathrm{CD}^{-} \mathrm{CD}^{+}\right)$shows that the relative percentage of $\mathrm{CD}^{-} \mathrm{CD}^{+}$of (Ag+BioMed) group increased notably after challenge. Otherwise, during the whole experiment, no variation in the population of $\mathrm{CD}^{+} \mathrm{CD}^{-}$was detected (data not shown).

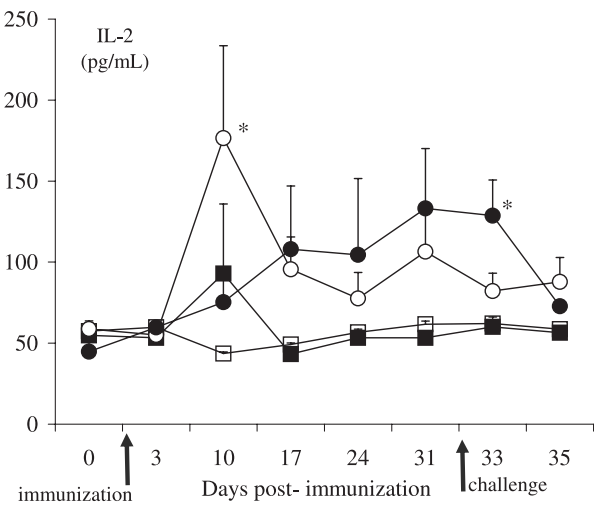

Figure 5. Detection of Interleukin-2 (IL-2) in PBMC following in vitro stimulation. Analysis of the IL-2 response of pig PBMC (Ctl- $\square$;

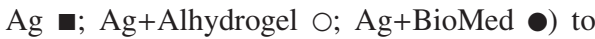
viral stimulation. The PBMC supernatant IL-2 concentration $(\mathrm{pg} / \mathrm{mL})$ was determined for each animal by a quantitative commercial ELISA kit (Materials and methods). The plotted results are the mean $(n=6) \pm$ SEM. Data points sharing the symbol $(*)$ are significantly different $(p<0.05)$.

\subsubsection{Cytokine production}

The profiles of the cytokines evaluated are good immunological parameters. The levels of IL-2, IL-4 and IFN- $\gamma$ secreted by the PBMC specific of the virus became detectable from day 10 post-immunization. At day 10, the (Ag+Alhydrogel) group shows a higher production for all these cytokines, but this production was only significant for IL-2 ( $p=0.047)$ (Fig. 5). For IFN- $\gamma$, the production was significant at days 17, 24 and 31 for three groups of pigs $\mathrm{Ag}$, (Ag+Alhydrogel) and (Ag+BioMed) (Fig. 6). After the challenge, the $(\mathrm{Ag}+\mathrm{BioMed})$ group distanced itself from the others in maintaining its IL-2 maximal level (about $130 \mathrm{pg} / \mathrm{mL}$ ) up to day 33 (2nd day post-challenge) $(p=0.007)$ while this concentration decreased to $50 \mathrm{pg} / \mathrm{mL}$ for pigs of other groups (except for (Ag+Alhydrogel): $70 \mathrm{pg} / \mathrm{mL}$ ). During this post-challenge 


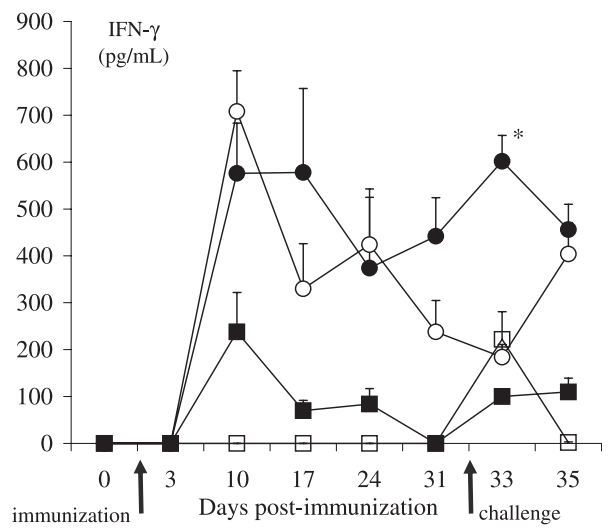

Figure 6. Interferon- $\gamma(\mathrm{IFN}-\gamma)$ production in PBMC following in vitro stimulation. Analysis of the IFN- $\gamma$ response of pig PBMC (Ctl$\square ; \mathrm{Ag} \mathbf{\square}$ Ag+Alhydrogel $\bigcirc$; $\mathrm{Ag}+\mathrm{BioMed} \bullet$ ) to viral stimulation. The PMBC supernatant IFN- $\gamma$ concentration $(\mathrm{pg} / \mathrm{mL})$ was determined for each animal by a quantitative commercial ELISA kit, (Materials and methods). The plotted results are the mean $(n=6) \pm$ SEM. The data point with the symbol $(*)$ is significantly different $(p<$ $0.05)$.

period, the group $(\mathrm{Ag}+\mathrm{BioMed})$ shows a higher production $(p=0.03)$ of IFN- $\gamma$ at day 33 post-immunization ( 2 days postchallenge). IL-4 production was low for all the groups and there was no significant difference between them (data not shown).

\subsection{Protection from homologous challenge infection}

One month after immunization, the pigs were challenged by intranasal nebulization with an experimentally established dose of $50 \mathrm{PID}_{50}$ (data not shown). Body temperatures were monitored daily from one day before the challenge until euthanasia 4 days later. This parameter did not seem reliable (individual differences of the physiological temperature and fluctuations according to stress). However, considering body temperature $\geq 40{ }^{\circ} \mathrm{C}$ as fever, it appears that on post-challenge day 3, all pigs (6/6) of the (Ag+BioMed) group had a normal temperature (group Ctl-: 3/6, group Ag: $4 / 6$ and group (Ag+Alhydrogel): 5/6).

\subsubsection{Macroscopic examination of the lungs}

Four days post-challenge, macroscopic lesions found in the lungs of the pigs of each group were counted. All pigs of the $\mathrm{Ctl}-, \mathrm{Ag}$, and (Ag+Alhydrogel) groups showed specific lesions from the influenza virus. In the group immunized with (Ag+BioMed), 4 pigs (of 6) show no macroscopic lesion in their lungs. Considering the mean of the total number of lesions, significant differences $(p=0.046)$ existed between the $(\mathrm{Ag}+\mathrm{BioMed})$ group $(0.5 \pm 0.5)$ and the (Ag+Alhydrogel) group $(4.7 \pm 2.5)$. For the $\mathrm{Ctl}-$ and $\mathrm{Ag}$ groups, the mean numbers of lesions were respectively $9.3 \pm 1.8$ and $8.2 \pm 1.8$. The size of the lesions was evaluated as lesion area (Fig. 7). These areas ranged from

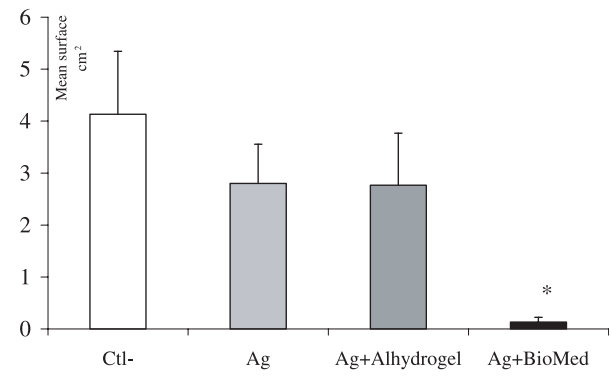

Figure 7. Mean surface of pulmonary lesions of pigs following intranasal challenge with H1N1 influenza virus. Lesions were measured $\left(\mathrm{cm}^{2}\right)$ in the lungs of each animal at the 4th day post-challenge. Each bar (Ctl- $\square$; Ag 匹; $\mathrm{Ag}+$ Alhydrogel $\square$; $\mathrm{Ag}+\mathrm{BioMed}$ ш) represents the mean surface $(n=6) \pm$ SEM. The data point with the symbol $(*)$ is significantly different $(p<0.05)$. 


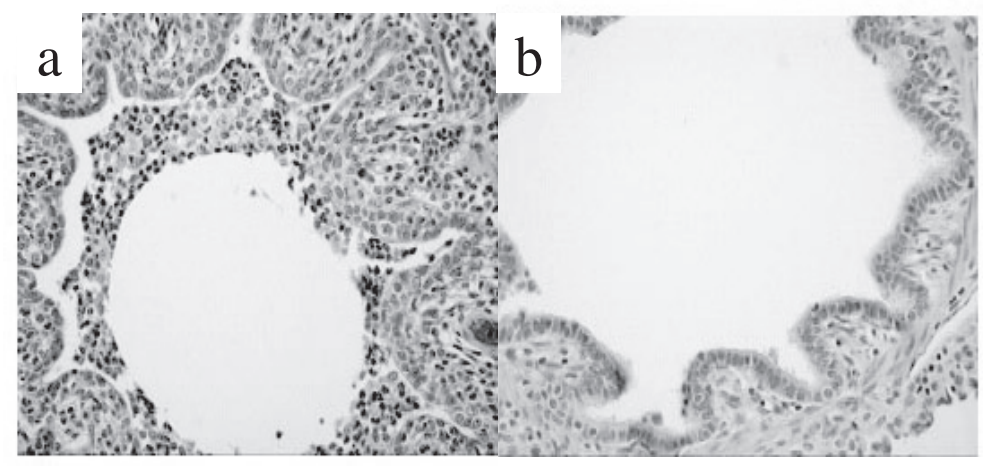

Figure 8. Histopathological examination of lungs from pigs following intranasal challenge with H1N1 influenza virus. Hematoxylin-phloxin-saffron (HPS) stained sections of lungs from Ag (a) and $(\mathrm{Ag}+\mathrm{BioMed})$ (b) groups. Lesions in the $\mathrm{Ctl}-, \mathrm{Ag}$ and (Ag+Alhydrogel) were qualitatively similar, consisting of subacute necrotizing bronchitis/bronchiolitis with interstitial pneumonia in adjacent alveolar septa (broncho-interstitial pneumonia). In contrast, bronchic/bronchiolar damage was minimal to absent in the BioMed group, with only interstitial pneumonia. (A color version of this figure is available at www.edpsciences.org/vetres.)

$0.1 \mathrm{~cm}^{2}$ to $10 \mathrm{~cm}^{2}$. The mean lesion area of the BioMed group was significantly lower $(p=0.03)$.

\subsubsection{Histopathological examination of the lungs}

The observed lesions, considered characteristic of influenza, showed a bronchus and bronchiole epithelium that varied in appearance (diminished to hyperplasic). The cytoplasm was generally basophilic. Other additional alterations in the bronchus and bronchioles were also observed: variable quantities of leukocytes (neutrophils and macrophages) and fibrin in the lumen, infiltration of the chorion by a moderate amount of leukocytes (mononuclears and eosinophils), an interstitial pneumonia characterized by a mononuclear cell infiltration in the alveolar septa, particularly in the bronchiole periphery. Histopathological lesions were classified in 4 categories depending on the intensity of the above alterations. In the control group, most animals show major modifications $(3+$ and
$4+)$. In the group of the animals immunized with the antigen only, most pigs were found in category $2+, 3+$. In the group of the animals immunized with the $(\mathrm{Ag}+$ Alhydrogel $)$, most pigs were found in category + and $2+$. For three of the animals belonging to ( $\mathrm{Ag}+\mathrm{BioMed})$, a focal lesion limited to rare bronchioles was observed (+) and the histopathology of the lungs showed no modification (-) for the three other pigs of this group. Figure 8 (a) represents a stained section of lungs from the Ag group where subacute bronchiolitis is characterized by immature attenuated to hyperplastic epithelium, and desquamated cells admixed with leukocytes in the lumen. On the contrary, Figure 8 (b) represents a stained section of lungs from the (Ag+BioMed) group where the bronchiole are normal.

\subsubsection{Virus titration of lung tissue}

The results are presented in Figure 9. In all pigs belonging to groups $\mathrm{Ctl}-, \mathrm{Ag}$ 


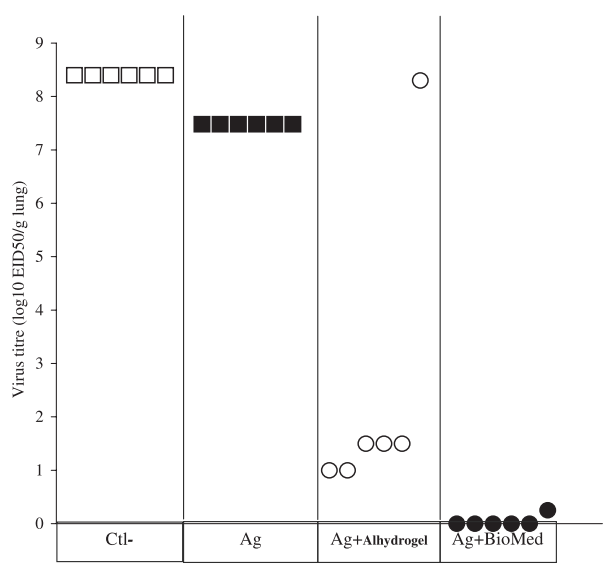

Figure 9. Virus titers in the lungs of pigs following intranasal challenge with H1N1 influenza virus. Quantification of virus recovered from lungs after challenge with $\mathrm{Sw} / \mathrm{In} / 1726 / 88$ virus in unvaccinated control pigs $(\mathrm{Ctl}-\mathrm{\square})$ and pigs vaccinated with different vaccinal preparations containing antigen alone (Ag घ), or antigen with Alhydrogel ${ }^{\circledR}$ $(\mathrm{Ag}+$ Alhydrogel $\mathrm{O})$ or antigen with BioMed adjuvant (Ag+BioMed ๑). The dots represent individual virus titers at 4 days postchallenge. Virus titers recovered from the lungs of $(\mathrm{Ag}+\mathrm{BioMed})$ group animals are significantly lower $(p<0.05)(*)$.

and (Ag+Alhydrogel), virus was detected in the samples of pulmonary tissues. In the group immunized with (Ag+BioMed), 5 piglets were free of virus in their lungs.

\section{DISCUSSION}

We used the porcine strain of influenza $\mathrm{A} / \mathrm{Sw} / \mathrm{IN} / 1726 / 88 \mathrm{H} 1 \mathrm{~N} 1$ in the pig as a study model to investigate the efficiency of the BioMed delivery system as antiviral inactivated vaccine adjuvant after one injection. The performance of this adjuvant was evaluated using the common aluminium hydroxyde-based adjuvant, Alhydrogel ${ }^{\circledR}$ as a reference. Our study was based on two criteria: the estimate of protection level of animals exposed to a homologous challenge and the follow-up of the parameters of the immune (humoral and cell mediated) response. Finally, our objective was to establish a correlation between the protection level observed and an immunological profile, with the factors of protection of the swine immune system against the influenza virus not yet clearly being defined.

In this study, pigs were submitted to a homologous challenge of $50 \mathrm{PID}_{50}$ one month after a single immunizing or control injection. The assessment criteria of the protection level of these animals were the following: (1) macroscopic examination of the lungs (number and area of the pulmonary lesions), the histopathological examination of these lesions and (2) viral titration in the lungs [3-5, 14, 15].

In the BioMed group of animals, 4 pigs (out of 6) were free of macroscopic lesion, while lesions could be seen in all individuals of other groups. For the other two animals of this group, lesions were limited to rare bronchioles and their cumulated area represented only $1 \mathrm{~cm}^{2}$. The quantification of the level of viral replication in the lung is also a key parameter to evaluate the protection. Indeed, one objective of a vaccination campaign is to contain the viral transmission to contact animals and in the case of influenza, to prevent the excretion of the virus by air. Virus was found in only one animal (out of 6) of the (Ag+BioMed) group whereas all other animals of other groups had virus in their lungs. Considering the above criteria, the results of the challenge show that the protection given by the BioMed formulation is higher than that of the Alhydrogel ${ }^{\circledR}$ adjuvant.

The second efficiency comparison factor was to evaluate, on a weekly follow-up basis, selected parameters of the immune response and to establish links between the results of the challenge and those of the immunological follow-up. The humoral response has been estimated by measurement of anti-hemagglutinin (HI) 
circulating antibodies [3-5, 34]. Only the group of pigs immunized with the BioMed formulation antigen shows significant concentrations in HI serum antibodies. The cell mediated immunity (CMI) acts as a direct regulator on the immune response and is essential for immunity against intracellular pathogens including viruses [19, 35]. Therefore, the evaluation of the CMI is a good indicator of the anti-viral immunity of the host $[17,18]$. In this study, we were able to identify the lymphoproliferative activity in response to an in vitro viral stimulation in immunized pigs with antigen alone or adjuvant. The profiles of the cytokines evaluated are also good immunological parameters. Indeed, IL-2 is secreted by activated lymphocytes and supports the in vitro proliferation. Its production is representative of PBMC activation [7,8]. The swine IL-4 activates NK and macrophage and is important for swine protection [20]. The production of IFN- $\gamma$, observed in response to different swine viruses, is an indicator of cell mediated profile [28].

During the pre-challenge period, whether it concerns PBMC proliferation, doubly-marked cells or cytokine production, the difference is not significant between the two groups, $(\mathrm{Ag}+\mathrm{BioMed})$ and (Ag+Alhydrogel) except for days 17 and 31 post-immunization. The relative concentrations in IL-2, IFN- $\gamma$ and IL-4 account for a Th-1 profile. Non-specific immune response to influenza virus infection includes the production of cytokines, particularly IFN- $\gamma$, and the activation of natural killer (NK) cells. NK cells kill infected cells, and thus limit replication and spread of the virus. The IFN- $\gamma$ produced early (day 10) in infection may reduce viral spread by inducing an antiviral state in host cells and by activation of $\mathrm{T}$ lymphocyte and NK cells, thereby contributing to recovery from infection $[13,18,20,30]$.

Two days after the challenge, only the $\mathrm{CD} 4^{+} \mathrm{CD}^{+}$of the pigs of BioMed treatment proliferate significantly compared to the same population of other groups. These cells are memory cells that proliferate specifically and produce IFN- $\gamma[22,31,39]$. Indeed, for the (Ag+BioMed) group, we noted a concomitant increase (day 2 postchallenge) of the relative percentage of $\mathrm{CD}^{+}{ }^{+} \mathrm{CD}^{+}$and of IFN $-\gamma$ concentration. Otherwise, when $\mathrm{CD}^{-} \mathrm{CD} 8^{+}$increased notably after challenge, no variation in the $\mathrm{CD} 4{ }^{+} \mathrm{CD}^{-}$population could be seen (data not shown). This phenomenon would be in line with the phenotypic change $\mathrm{CD}^{+}{ }^{+} \mathrm{CD} 8^{-}$into $\mathrm{CD} 4^{+} \mathrm{CD} 8^{+}$suggested by the Waters team [36]. For the groups $(\mathrm{Ag}+\mathrm{BioMed})$ and $(\mathrm{Ag}+$ Alhydrogel $)$, a decrease in relative percentage of doubly marked cells was observed on day 4 postchallenge. It is likely that the migration toward the (pulmonary) infection site of this lymphocytic population leads to a concomitant depletion in the peripheral blood. To summarize, the (Ag+BioMed) and (Ag+Alhydrogel) groups show a type Th- 1 cell proliferation that is roughly identical, except for day 2 post-challenge with a higher proliferation of $\mathrm{CD} 4^{+} \mathrm{CD} 8^{+} \mathrm{T}$ cells for the $(\mathrm{Ag}+\mathrm{BioMed})$ group.

Consequently, the question can be asked: which factor(s) led to a better resistance of the animals of the group (Ag+BioMed) in view of the challenge? Various studies ([21] and references herein) tend to show that the level of protection given by an $\mathrm{H} 1 \mathrm{~N} 1$ influenza strain based vaccine in pigs would be correlated with the serum anti-hemagglutinin (HI) level. A concentration of $1 / 40$ [16] would be sufficient to prevent the viral replication in the respiratory system, giving a full protection to animals. In this study and just before the challenge, three pigs of the BioMed group had concentrations considered as being protective, which would alone justify that no lesions and no viral replication were detected in the lungs of these animals.

Nevertheless, it emerges ([12, 21, 25] and references herein) that the protection 
of pigs against influenza probably could depend on more than one form of immune response. This protection would be correlated to the titers of specific serum antibodies and the immune cell response would accelerate the 'clearance' process of the virus, rather than to prevent the initial infection. Moreover, indirect evidence inclines to think that $\mathrm{CD} 4^{+} \mathrm{CD}^{+}$activated lymphocyte mediated cytolytic functions $[2,9,24]$.

The significantly lower number of lung lesions in the $(\mathrm{Ag}+\mathrm{BioMed})$ group shows that antibodies acted in the prevention of the infection: three pigs of the group (Ag+BioMed) had neither pulmonary lesions nor virus in their lungs. In addition, the comparison of the levels of either viral multiplication in the lungs or number of lesions of the groups (Ag+Alhydrogel) and $\mathrm{Ag}$ (alone) suggests that there was an active participation of the cell immunity in the eradication of the infection, which could, however, not be prevented due to insufficient antibody titres. Taken altogether, the best protection in view of the challenge of the pigs of the group (Ag+BioMed) seems to be correlated both to a higher level of antibody response and perhaps to the production of $\mathrm{CD} 4^{+} \mathrm{CD} 8^{+}$memory $\mathrm{T}$ cells, so that an active participation of cell mediated immunity can not be excluded.

Which factor(s) can explain the BioMed adjuvant efficiency? It is a biphasic system combining a colloidal phase formulated from an oil-in-water emulsion, to an Alhydrogel ${ }^{\circledR}$ phase through electrostatic interactions. First, components of the emulsion can modulate the immune response: Vitamin $\mathrm{E}$ and $\mathrm{A}$ are associated with increased systemic humoral and CMI responses. Second, a tissue distribution study in mice shows that this carrier has a propensity for macrophage-rich tissue of the reticulo-endothelial system. Third, this emulsion can induce a slow release of the antigen or increase the contact area between the vaccine and the medium, therefore increase its contact time with the immune system. All these factors may participate in the efficiency of this new carrier.

\section{ACKNOWLEDGEMENTS}

The authors thank Dr Y. Chorfi for his assistance in sampling and handling the animals. They also thank G. Beauchamp for statistical study and B. Bousquet for her excellent technical assistance. The authors are grateful to $\mathrm{Dr}$ K. Van Reeth for interesting comments, Dr C. Holliman, J. Kashul and J. Lewandowski for improving our English. The study was financially support by Les laboratories BIO-MED Inc.

\section{REFERENCES}

[1] Barrett T., Inglis S.C., Growth, purification and titration of influenza virus, in: Mahy B.W.J., Virology, a practical approach, IRL Press Oxford, Washington, 1985, pp. 119150.

[2] Bassaganya R.J., Hontecillas R., Zimmerman D.R., Wannemuehler M.J., Long-term influence of lipid nutrition on the induction of $\mathrm{CD}^{+}$responses to viral or bacterial antigens, Vaccine (2002) 20:1435-1444.

[3] Bikour M.H., Cornaglia E., Elazhary Y., Comparative study of the immunnostimulatory properties of different adjuvants administered with in inactivated influenza virus vaccine and evaluation of passive immunity in pigs, Immunol. Infect. Dis. (1994) 4:166172.

[4] Bikour M.H., Cornaglia E., Weber J.M., Elazhary Y., Antigenic characterization of an H3N2 swine influenza virus isolated from pigs with proliferative and necrotizing pneumonia in Quebec, Can. J. Vet. Res. (1994) 58:287-290.

[5] Bikour M.H., Cornaglia E., Elazhary Y., Evaluation of a protective immunity induced by an inactivated influenza $\mathrm{H} 3 \mathrm{~N} 2$ vaccine after an intratracheal challenge of pigs, Can. J. Vet. Res. (1996) 60:312-314.

[6] Brown I.H., The epidemiology and evolution of influenza viruses in pigs, Vet. Microbiol. (2000) 74:29-46. 
[7] Charley B., Petit E., Leclerc C., Stefanos S., Production of porcine interleukine- 2 and its biological and antigenic relationships with human interleukine-2, Immunol. Lett. (1985) 10:121-126.

[8] Charley B., Fradelizi D., Differential effects of human and porcine interleukine 2 on natural killing (NK) activity of newborn piglets and adult pigs lymphocytes, Ann. Rech. Vet. (1987) 18:227-232.

[9] De Bruin T.G.M., Van Rooij E.M.A., De Visser Y.E., Bianchi A.T.J., Cytolytic function for Pseudorabis Virus-Stimulated Porcine $\mathrm{CD} 4{ }^{+} \mathrm{CD} 8{ }^{\text {dull }+}$ Lymphocytes, Viral Immunol. (2000) 13:511-520.

[10] Easterday B.A., Hinshaw V.S., Swine influenza, in: Leman A.D. et al. (Eds.), Disease in swine, Iowa State press, Ames, 1992, pp. 349-357.

[11] ElAzhary Y., Makabi-Panzu B., Hurley D.J., Laurent S., Delivery system for entrapping charged macromolecules and a method for preparing same, US patent No. 6,5552,004, 2003.

[12] Epstein S.L., Chia-Yun L., Misplon J.A., Bennink J.R., Mechanism of protective immunity against influenza virus infection in mice without antibodies, J. Immunol. (1998) 160:322-327.

[13] Foss D.L., Murtaugh M.P., Role of macrophage cytokines in mucosal adjuvanticity, Adv. Vet. Med. (1999) 41:83-104.

[14] Gourreau J.M., Hannoun C., Kaiser C., Jestin A., Excretion of human influenza virus by experimentally infected pigs, Comp. Immunol. Microbiol. Infect. Dis. (1980) 3:137-146.

[15] Haesebrouck F., Biront P., Pensaert M.B., Leunen J., Epizootics of respiratory tract disease in swine in Belgium due to H3N2 influenza virus and experimental reproduction of disease, Am. J. Vet. Res. (1985) 46:19261928.

[16] Haesebrouck F., Pensaert M.B., Effect of intratracheal challenge of fattening pigs previously immunized with an inactivated influenza H1N1 vaccine, Vet. Microbiol. (1986) 11:239-249.

[17] Heinen P.P., van Nieuwstadt A.P., de BoerLuijtze E.A., Bianchi A.T., Analysis of the quality of protection induced by a porcine influenza A vaccine to challenge with an $\mathrm{H} 3 \mathrm{~N} 2$ virus, Vet. Immunol. Immunopathol. (2001) 82:39-56.

[18] Heinen P.P., Rijsewijk F.A., de Boer-Luijtze E.A., Bianchi A.T., Vaccination of pigs with a DNA construct expressing an influenza virus M2-nucleoprotein fusion protein exacerbates disease after challenge with influenza A virus, J. Gen. Virol. (2002) 83:1851-1859.

[19] Janeway C.A., Travers P., Walport M., Capra J.D., Host defense against infection, in: Immunobiology: The Immune System in Health and Disease, Elsevier/Garland, Amsterdam/London, 1999, pp. 363-415.

[20] Knoblock K.F., Canning P.C., Modulation of in vitro porcine natural killer cell activity by recombinant interleukine-1 alpha, interleukine-2 and interleukine-4, Immunology (1992) 76:229-304.

[21] Larsen D.L., Karasin A., Zuckermann F., Olsen C.W., Immunization of pigs against influenza virus infection by DNA vaccine priming followed by killed-virus vaccine boosting, Vaccine (2001) 19:2842-2853.

[22] Meier W.A., Galeota J., Osorio F.A., Husmann R.J., Schnitzlein W.M., Zuckermann F.A., Gradual development of the interferon-gamma response of swine to porcine reproductive and respiratory syndrome virus infection or vaccination, Virology (2003) 25:18-31.

[23] Meulemans G., Inter-species transmission of the influenza virus, Bull. Mem. Acad. R. Med. Belg. (1999) 154:263-267.

[24] Moskophidis D., Kioussis D., Contribution of virus-specific CD8+ cytotoxic T cells to virus clearance or pathologic manifestations of influenza virus infection in a $\mathrm{T}$ cell receptor transgenic mouse model, J. Exp. Med. (1998) 188:223-232.

[25] Olsen C.W., Carey S., Hinshaw L., Karasin A.I., Virologic and serologic surveillance for human, swine and avian influenza virus infection among pigs in the north-central United States, Arch. Virol. (2000) 145:1399_ 1419.

[26] Pastoret P.P., Veterinary vaccinology, C.R. Acad. Sci. Paris, Sciences de la vie - Life Sciences, 32, 1999, pp. 927-967.

[27] Pescovitz M.D., Sakopoulos A.G., Gaddy J.A., Husman R.J., Zuckermann F.A., Porcine peripheral blood $\mathrm{CD}^{+} \mathrm{CD} 8^{+}$ dual expressing T-cells, Vet. Immunol. Immunopathol. (1994) 43:53-62.

[28] Rodriguez-Carreno M.P., Lopez-Fuertes L., Revilla C., Ezquerra A., Alonso F., Dominguez J., Phenotypic characterization of porcine IFN-gamma-producing lymphocytes by flow cytometry, J. Immunol. Methods (2002) 259:171-179. 
[29] Saalmuller A., Pauly T., Hohlich B.J., Pfaff E., Characterization of porcine $\mathrm{T}$ lymphocytes and their immune response against viral antigens, J. Biotechnol. (1999) 20:223233.

[30] Salmon H., Charley B., Labonnardiere C., Olivier M., Kelley K., Paraf A., Natural killer (NK) activity and interferon (IFN) production by a fraction of spleen and blood lymphocytes in swine, Vet. Immunol. Immunopathol. (1989) 23:113-128.

[31] Summerfield A., Rziha H.J., Saalmuller A., Functional characterization of porcine CD4+CD8+ extrathymic T-lymphocytes, Cell. Immunol. (1996) 168:291-296.

[32] Suzuki T., Horiike G., Yamazaki Y., Swine influenza virus strains recognize sialylsugar chains containing the molecular species of sialic acid predominantly present in the swine tracheal epithelium, FEBS Lett. (1997) 404:192-196.

[33] Thompson W.R., Use of moving averages and interpolation to estimate medianeffective dose: I. Fundamental formulas, estimation of error, and relation to other methods, Bacteriol. Rev. (1947) 11:115-145.
[34] Van Reeth K., Labarque G., De Clercq S., Pensaert M., Efficacy of vaccination of pigs with different $\mathrm{H} 1 \mathrm{~N} 1$ swine influenza viruses using a recent challenge strain and different parameters of protection, Vaccine (2001) 4:4479-4486.

[35] Van Reeth K., Van Gucht S., Pensaert M., Correlations between lung proinflammatory cytokine levels, virus replication, and disease after swine influenza virus challenge of vaccination-immune pigs, Viral Immunol. (2002) 15:583-594.

[36] Waters W.R., Hontecillas R., Sacco R.E., Zuckermann F.A., Harkins K.R., Bassaganyariera J., Wannemuehler M.J., Antigen-specific proliferation of porcine CD8 $\alpha \alpha$ cells to an extracellular bacterial pathogen, Immunology (2000) 101:333341.

[37] Wuethrich B., Chasing the Fickle Swine flu, Science (2003) 299:1502-1505.

[38] Zuckermann F.A., Husmann R.J., Functional and phenotypic analysis of porcine peripheral blood CD4/CD8, Immunology (1996) 87:500-512.

[39] Zuckermann F.A., Extrathymic CD4/CD8 double positive $\mathrm{T}$ cells, Vet. Immunol. Immunopathol. (1999) 15:55-66. 